\author{
JAKUB PIVARČ \\ Charles University \\ in Prague
}

\title{
PUPILS' MISCONCEPTIONS AS A PSYCHOSOCIAL BARRIER IN THE CONTEXT OF INCLUSIVE EDUCATION
}

\begin{abstract}
Pivarč Jakub, Pupils' Misconceptions as a Psychosocial Barrier in the Context of Inclusive Education [Błędne wyobrażenia uczniów jako bariera psychospołeczna w kontekście edukacji włączającej]. Studia Edukacyjne nr 37, 2015, Poznań 2015, pp. 363-376. Adam Mickiewicz University Press. ISBN 978-83-232-2967-4. ISSN 1233-6688. DOI: 10.14746/se.2015.37.21
\end{abstract}

During the totalitarian regime the Czech education system significantly hindered or entirely prevented pupils with a developmental disability to exercise their right to education. Since 1989, the Czech schooling system has undergone a distinct transformation. In line with the qualities of today's postmodern society, the idea of inclusion has been one of the changes, but has been evolving only at a theoretical level so far. Inclusive education is clearly a solution for pupils with a developmental disability, which in turn leads to equal and effective education. Some obstacles within the practical application of inclusion may be negative attitudes, incorrect understanding, prejudices and invalid generalisations (misconceptions) of intact pupils about their peers who have a developmental disability. The paper discusses psychosocial barriers at a microsocial level in a classroom which may inhibit the inclusion process. The main focus is on the issue of pupils' misconceptions and some strategies to overcome them.

Key words: transformation in education, inclusion, psychosocial barriers, misconceptions, developmental disability

\section{Introduction}

In the globalising postmodern society we need to cultivate an ethical approach to our fellowmen. It has become an utmost necessity to deal with issues of social solidarity, tolerance and commitment for the benefit of those directly dependent on it - i.e. people with a disability.

Since the velvet revolution it has become clear that the interests of the Czech governmental representatives have taken an ever increasing stand on 
reducing the barriers systematically which hamper or even entirely prevent the people with disability to integrate into the life of the majority within our society. In terms of quality and values, the system of care for people with disability has changed in the last two decades. This is in compliance with the principles and trends of humanism based on the religious tradition of our country and it is rooted in the Christian values of charity, love and selfless help to those who need it.

The 21st century axiological dimensions of developed democratic countries including the Czech Republic reflect social goals declaring the values of cohesion, freedom, justice, equality, moral responsibility, tolerance and respect for diversity and human heterogeneity in particular. These values have been emphasised in a range of treaties, policies, strategic concepts and documents at international, national and municipal levels. Their fundamental function is to overcome social and psychological barriers (prejudices of the intact population, stereotypes, incorrect understanding, or xenophobia) against unfamiliarity, and this includes people with a disability who are a diverse and numerous part of the population.

People with intellectual disability have a highly specific status. Firstly, they are one of the most numerous groups of disabled people, and secondly, they are perceived by the intact population in a more negative way than people with other forms of disability ${ }^{1}$. This group has also a higher risk of social exclusion, segregation and marginalisation. Despite the well-known facts from the scientific and professional community, we have little understanding of the intellectual disability phenomenon. Research studies should also provide a solution to this problem regarding the understanding and notions held by the intact lay population about this worldwide phenomenon. People's perceptions and conceptions of intellectual disability are often afflicted by unclear, incomplete information, misconceptions, prejudices and hostile attitudes that stem from idle fear. Švarcová 2 suggests that some people still think (even some professionals such as physicians) that disabled people should be "cleared away" into specialised facilities in order to be out of sight of those who are "normal" and healthy. Such an approach of the "healthy - normal" population to people with intellectual disability significantly hinders (or even restricts) their integration into society, or inclusion respectively. Being able to understand and transform the negative attitudes (misconceptions) is an important prerequisite to practically implement and establish "inclusive" trends.

${ }^{1}$ K. Scior, Public Awareness, Attitudes and Beliefs Regarding Intellectual Disability: A Systematic Review, Research in Developmental Disabilities, 2011, 32, 6.

2 I. Švarcová, Mentální retardace: Vzdělávání, výchova, sociální péče, Praha 2006, p. 13. 


\section{Inclusion and inclusive education as a value concept of democratic society}

The concept of inclusion within a wide social context may be defined according to Booth and Ainscow (In Farrell and Ainscow ${ }^{3}$ ) as: "Inclusion is a process in which schools, communities, local authorities and governments strive to reduce barriers to the participation and learning for all citizens". However, the quality of social inclusion is largely the result of the inclusion process within education. Every developed democratic society should reflect previously mentioned values of cohesion, freedom, justice, equality, moral responsibility, tolerance and respect for diversity and human heterogeneity, particularly within the area of education. At the institutional level, the values should be followed by primary and lower secondary ${ }^{4}$ schools in particular. In the process of socialisation, the primary education presents a life stage where interaction, encounter and social contact take place among the heterogeneous pupil population inside a central social institution which has a unique and irreplaceable role in each person's life. School cannot be perceived as a mere provider of knowledge, but according to Lebeer ${ }^{5}$ as an institution passing on norms of social behaviour and values, forming attitudes to others and where natural environment for practicing social skills and moral behaviour may be utilised.

Influenced by social changes and priorities of Czech society - particularly after 1989 - the principles of equal opportunities should be emphasised even more so against the discriminatory attitudes in favour of a high quality education for all pupils/students (thus including people with a disability) in the least restrictive environment possible. For the last twenty years Czech primary schooling has undergone a prominent transformation, paradigm encounters, conceptual and structural changes, and has adopted new goals in education. A primary outcome of this shift is the idea of inclusive education which opposes the exclusion of pupils with special educational needs into a separate system of schooling (i.e. practical or special schools).

The term inclusive education refers to the reality of life which takes place in a mainstream school where the physical, intellectual, emotional, social, linguistic and cultural heterogeneity is accepted (welcomed) and where de-

${ }^{3}$ P. Farrell, M. Ainscow (Eds.), Making Special Education Inclusive: From Research to Practice, London 2002, p. 3.

${ }^{4}$ Author's note: Primary school education refers to ISCED 1 and lower secondary school education to ISCED 2 (International Standard Classification of Education, 2011).

5 J. Lebeer (Ed.), Programy pro rozvoj myšlení dětí s odchylkami vývoje: podpora začleňování znevýhodněných dětí do běžného vzdělávání, Praha 2006. 
sirable, the development of all pupils with no exceptions is being achieved with regard to their individual educational needs and their potential.

Inclusive education affects all pupils who have individual educational needs (thus not only those with special needs). In accordance with the UNESCO document it is essential not to overlook the groups of pupils who are at a higher risk of marginalisation and exclusion. This indicates moral responsibility to carefully monitor the groups that are statistically more at risk and to make necessary steps where possible to ensure the presence, participation and achievement in the education system ${ }^{6}$. One of the groups which is statistically most at risk of marginalisation in the Czech Republic are pupils with intellectual disability who are also the largest group with disability. The relevant statistical data and data from the Ministry of Education, Youth and Sports (Annual Statistics 2013/2014) reveal that those are pupils educated primarily outside of mainstream education. Only $8 \%$ of pupils with intellectual disability have been integrated within the mainstream primary schools (it should be added that this trend is on the rise as in 2009/2010 they were only $4.4 \%$ ).

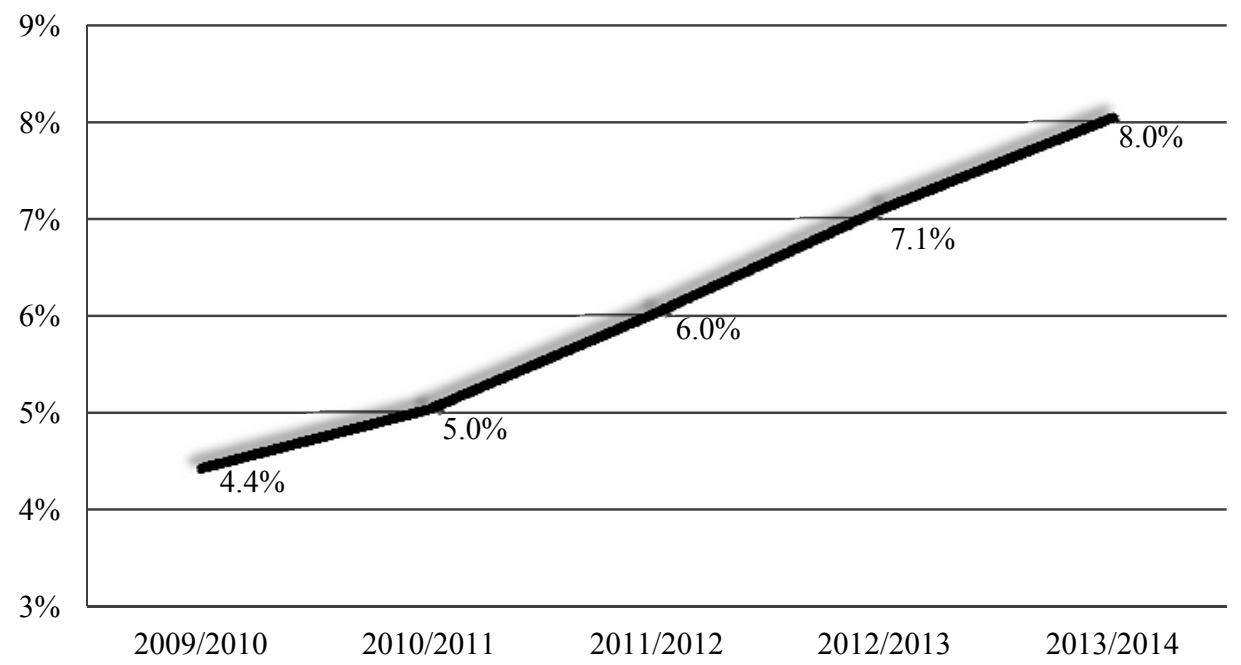

Fig. 1. Ratio of integrated pupils out of all pupils with intellectual disability into mainstream schools (school year 2009/2010 up to 2013/2014)

${ }^{6}$ United Nations Educational, Scientific and Cultural Organization, Guidelines for Inclusion: Ensuring Access to Education for All, Paris 2005, p. 16. 
The right of pupils with intellectual disability to gain mainstream education and equality in such education has been fulfilled rather sporadically, despite the legislative, financial and other measures implemented in the Czech Republic. Particularly the former Eastern bloc countries (e.g. Czech Republic, Slovakia, Poland, Hungary, Bulgaria and Romania) follow the trend of inclusive education of other, more developed, European states. The Czech education, however, may still be identified as a segregated and selective system. Educational needs of pupils with disability remain to be saturated outside the mainstream education, i.e. in practical or special schools. The Czech Republic has been facing an increasing demand of international and national authorities to reform its education system. Although some examples of good practice are known, we cannot claim that the Czech education system is currently able to adequately and conceptually ensure inclusive education nationwide. Barriers that need to be addressed (to reach successful inclusion) may be registered at macrosocial, mezzosocial and microsocial levels that are briefly outlined in the following text. However, the focus is on the issue of pupils' misconceptions which form a significant obstacle at the microsocial level of a classroom, and hence affect the process of inclusive education of pupils with (intellectual) disability.

\section{Psychosocial barriers in the process of inclusive education}

In line with the transformative efforts under current conditions in Czech education we may find many factors influencing the process of inclusion and its success. Generally we encompass factors applied at the macrosocial level, i.e. transnational and national level (e.g. legislative framework for education, concepts and strategies of education policy); mezzosocial, i.e. a particular school (e.g. dimension of a school culture and its values, organisational requirements, personal, material or financial provisions) and finally, at microsocial level, i.e. a classroom (this level includes the psychosocial aspects or variables related to psychological and social factors impacting on a relationship between pupils with and without disability). The levels stated above intertwine, and as a complex factor they are required for a successful inclusion in education. However, separately they may present certain barriers which restrain the inclusion process.

A considerable obstacle at the macrosocial level in the Czech Republic is the concept of the curriculum. It focuses mainly on pupils' performance and skills. A performance-focused curriculum represents an environment where 
the cognitive aims of education are monitored. Inadequate attention is given to the so called affective objectives, which are supposed to monitor the personal, civil and social development of pupils' competencies - this is essentially contradictory to the principles of inclusive education. The key civil, social and personal competencies of pupils should therefore be cultivated similarly to academic and other skills. Also the current Section 16 of Act No. 561/2004 Coll. on Pre-school, Basic, Secondary, Tertiary Professional and Other Education (The Education Act) poses some problems. The provisions do not e.g. specify a procedure to meet the educational needs of pupils with disabilities and socially disadvantaged. Moreover - de jure - the pupils' support is dependent on a diagnosis of their condition, which in effect discriminates those who have been given no diagnosis, but are clearly in need of increased support within the mainstream education (e.g. pupils with a borderline intellectual functioning).

At the mezzosocial level we may consider e.g. financial barriers (a lack of adequate tools for pupils with intellectual disability), professional (absence of a specialised training for teachers in primary and lower secondary school education; inadequate competence for collaboration with other professionals physicians, psychologists, specialised teachers), and interpersonal barriers (collaboration with parents of pupils with or without disability; mutual cooperation between teachers and those outside of the teaching profession), etc.

The transformation of a schooling system aiming for inclusion is also required at the microsocial level of a classroom. According to Šafr, Bayer and Sedláčková the microsocial level is irreplaceable, because cohesive society always develops due to particular modes of behaviour and attitudes, as opposed to some abstract nationwide concepts. The decisive platform where society develops includes particular interpersonal relations (local communities or social groups in particular) $)^{7}$. Research in the field of inclusive pedagogy is currently focused on the issues of practical application. The research studies intend to consider other relevant variables that determine the success to include pupils with intellectual disability into the mainstream education. Scholarly inquiry, particularly in other countries, focuses on identification, analysis and transformation of the negative attitudes in order to defeat the rigid notions, incorrect understanding and beliefs of individuals who determine and influence the process of inclusion directly (i.e. teachers, classroom assistants, pupils with special educational needs, parents, etc.). Besides, the research concentrating on the variables mentioned above is fully justified,

7 J. Šafr, I. Bayer, M. Sedláčková, Sociální koheze. Teorie, koncepty a analytická východiska, Sociologický časopis - Czech sociological review, 2008, 44, 2, p. 266. 
and this includes intact pupils. A wide-ranging research papers 8 support the idea that the quality of a rapport between pupils with and without intellectual disabilities in a mainstream school (this being the significant factor of successful inclusion) is influenced by the amount of relevant information, and the pupils' attitudes and notions about their peers with disability (overall preconceptions, i.e. pupil's interpretation of a particular concept/ phenomenon). Pupils' false ideas (misconceptions) and negative attitudes (prejudices or stereotypes) or their insufficient understanding of disability and problems experienced by pupils with disabilities are all key aspects for successful and inclusive education ${ }^{9}$.

\section{Pupil's misconception as a barrier to inclusive education}

Pupils enter education having various misconceptions about the world and its components. A misconception as a primary cognitive structure (i.e. preconception) refers to a pupil's incorrect or false notions about a phenomenon and its consequent incorrect interpretation. It is usually based on false or incomplete information, limited experience or some invalid generalisation. False conceptions develop in early childhood and may remain until adulthood. Misconceptions tend to be very firmly ingrained and form stable cognitive structures, because this incorrectly structured knowledge (in terms of current scientific knowledge as opposed to individual's knowledge) had been adopted in a distinctive way and proved to be suitable, correct and functional in that moment in the past. Information provided from the outer environment (mass media, family, school, friends, etc.) or a specific experience received from interaction with this environment causes an emotional response which manifests as an attitude to a particular phenomenon or a person. When we process and incorrectly structure information in our cognitive system (cognitive dimension of conception), inadequate attitudes may then be formed (affective dimension of conception). Misconception may therefore be projected as negative prejudices, stereotypes and invalid generalisations within particular attitudes and modes of behaviour of a pupil and

${ }^{8}$ G. Laws, E. Kelly, The Attitudes and Friendship Intentions of Children in United Kingdom Mainstream Schools towards Peers with Physical or Intellectual Disabilities, International Journal of Disability, Development and Education, 2005, 52, 2; C. Fox, E. Buchanan-Barrow, M. Barrett, Children's Understanding of Mental Illness: an Exploratory Study, Child: Care, Health and Development, 2007, 34, 1.

9 J. Sherman, S. Sherman, Preventing Mobility Barriers to Inclusion for People with Intellectual Disabilities, Journal of Policy and Practice in Intellectual Disabilities, 2013, 10, 4. 
directed at the concept, phenomenon, problem or a person - e.g. as an attitude to somebody with intellectual disability. Misconceptions need to be diagnosed at schools and modified using suitable teaching strategies. Diagnostics of pupils' misconceptions about intellectual disability are not, if at all, adequately addressed within the present teaching practices of Czech primary schools. Teachers and other professionals lack sufficient awareness of pupils' misconceptions of intellectual disability which may of course significantly impact on the process of inclusive education. As already mentioned, school is not only a place for knowledge transfer, but also for the shaping of prosocial behaviour and behavioural patterns.

In association with inclusion, pupils should be prepared in schools for future life in the society which will involve participation of people with disabilities and consequent valuable cooperation between the people with and without disabilities. Inability to understand and respect the differences results in rejection of those who are unlike the others (in terms of somatic and mental aspects). According to Vágnerová, Hadj-Mouss and Štech ${ }^{10}$ the intact population differentiates social importance of individual disabilities. As already mentioned, one of the groups most at risk of social exclusion, marginalisation and segregation are people with an intellectual disability. Even for teaching practice the risk is ongoing. Hence the question proposed is: How will pupils accept their peers with intellectual disability in inclusive school environment? If the nationwide pattern, attitudes and acceptance of people with disabilities is reflected, we could possibly find that in practice, intact pupils maintain rather negative attitudes towards their peers with intellectual disability compared to another type of disability (e.g. sensory impairment).

\section{Social exclusion of pupils with intellectual disability and options for dealing with misconceptions}

Reasons for social exclusion of pupils with intellectual disabilities may be diverse (e.g. limited level of their social and communicative competencies [see paper ${ }^{11}$, the difficulties in predicting their behaviour and actions, low adaptability, aesthetic aspect - visible deformations, etc.). Intellectual disabil-

${ }^{10}$ M. Vágnerová, Z. Hadj-Moussová, S. Štech, Psychologie handicapu, Praha 2001.

${ }^{11}$ E. Helmstetter, Ch. Peck, M. Giangreco, Outcomes of Interactions with Peers with Moderate or Severe Disabilities: A Statewide Survey of High School Students, Journal of the Association for Persons with Severe Handicaps, 1994, 19, 4.; J. Slowík, Komunikace s lidmi s postižením, Praha 2010. 
ity is usually associated with a considerable stigma, a very negative social role and status. This significantly affects the personality of a disabled person and forms his/her identity and self-concept. In a mainstream school where a pupil with disability is integrated, but not accepted by other pupils, other secondary problems may arise. In extreme cases, the pupil with disability may fall a victim of bullying or take on a role of aggressor (which is less typical). Socially rejected pupils are often faced with problems related to academic knowledge acquisition and common demands made from their school authority ${ }^{12}$. To a higher extent there are interpersonal conflicts with peers, feelings of anxiety, loneliness and isolation ${ }^{13}$. Furthermore, psychosomatic problems are not rare.

The mere presence (integration) of a pupil with intellectual disability in a mainstream class does not guarantee his/her full acceptance by other intact pupils. A teacher plays an important role in establishing an acceptable atmosphere among pupils with and without disabilities. The diagnostics of peer relations inside the class seem crucial (e.g. using sociometry), and so is the assessment of pupils' preconceptions and misconceptions about disability. This must be central and focused on notion analysis, and pupils' attitudes and opinions of intellectual disability. The diagnostics provide a teacher with up-to-date and valuable information and may also have a significant preventative character. Pupils' concepts (preconceptions) of intellectual disability may take a form of false notions (misconceptions) as already discussed above. For teaching practice the preconceptions and misconceptions are fundamental and determine the quality and success of inclusion. Based on the diagnostics of pupils' misconceptions appropriate didactical and organisational forms of work, particularly strategies, to overcome misconceptions, should be selected. Socially desirable patterns of behaviour, opinions, attitudes and consequently positive relations between pupils with and without (intellectual) disabilities are improved using cooperative activities (based on cooperative learning and linked to the system of so called peer programmes) rather than competitive activities which are typical of the traditional model of education.

- Peer programmes (with a wide range of activities such as peer tuition, mentoring, mediation, etc.) have an essential role in inclusive education and can be regarded as another important element in dealing with psychosocial

12 L. Tipton, L. Christensen, J. Blacher, Friendship Quality in Adolescents with and without an Intellectual Disability, Journal of Applied Research in Intellectual Disabilities, 2013, 26, 6.

13 J. McDougall et al., High School-Aged Youths' Attitudes toward their Peers with Disabilities: The Role of School and Student Interpersonal Factors, International Journal of Disability, Development and Education. 2004, 51, 3. 
barriers at a microsocial level of a classroom. Its fundamental principle is the social interaction among the peers. Peer interaction may occur during various (educational) activities and is often conditioned by a cooperative activity. For instance, peer learning stems from the fact that a pupil with higher performance, more intellectually and personally competent (as a tutor/ expert) shares knowledge or required key competencies with another pupil in a more natural way than a teacher does (who may not be as approachable, or able to empathise with the pupil to such extent and in terms of various aspects as his/her classmate). The peer learning outcome is that a child/ pupil having a tutor/expert role is more likely to identify with his/her tutored pupil-partner (be it in terms of needs, value systems, norms, preferences or opinions) and helps to update their potential cognitive stage of development.

- Cooperative learning may be understood in a wider context as a set of teaching methods when pupils cooperate to reach a goal, or solve a problem on a basis of mutual support. The primary outcome is that the learning takes place in heterogeneous groups of 2-6 pupils. Each pupil has an opportunity to apply his/her multiple skills, accept responsibility for own actions and share responsibility for the results of the group. However, educational process based on cooperation requires a teacher to largely facilitate the cognitive and social development of each pupil and carefully apply own managerial skills (particularly to divide pupils to groups as appropriate - be it according to their cognitive stage or attitudes, to help defining their roles, to structure tasks so that everyone in a group understands them, etc.).

Similarly to Bartoňová we consider social interaction between pupils with and without intellectual disability supported by cooperative activities as a crucial element of inclusion. It is very important to promote inclusion within a classroom as well as beyond. Maintaining social contact among all pupils has a positive impact, because pupils discover differences between themselves and people in general. Consequently, they learn to socialise with people with disabilities and learn from each other. When pupils with and without disability share one class, the social inclusion of a disabled pupil into mainstream society is more likely to take place ${ }^{14}$. Collaboration on lessons (and beyond) emphasises cognitive, but mainly affective and social objectives of education. It is an important tool in the teaching practice for overcoming misconceptions of intact pupils. It has been argued that the mere education does not bring a desired effect. However, if combined with

${ }^{14}$ M. Bartoňová, Některé aspekty inkluzivního vzdělávání v podminkách primárního školstoí, [In:] Inkluzivní vzdělávání v podminkách současné české školy, M. Bartoňová, M. Vítková et al., Brno 2010, p. 245-246. 
cooperative tasks, it is a significant factor for creating positive climate in a classroom (as documented by many research studies, see the text below) and for dealing with pupils' misconceptions.

A positive impact of cooperative activities on academic results of pupils with intellectual disabilities, on their rapport with intact peers and on ability to adapt to the needs of others was proven in many research studies ${ }^{15}$. Social interaction helps pupils with intellectual disabilities to develop their communication and social competences, which have a major impact on the improvement of other interpersonal relationships, particularly in adulthood ${ }^{16}$. Varied interactions evolve under inclusive conditions of heterogeneous social groups in particular those which manifest pupils' diverse experiences, needs, skills and knowledge as a part of their cooperative activities. In this process a reciprocal desire and need for learning from others occur, notably from more advanced (intact) peers. Lev S. Vygotsky proposed that higher mental functions develop under a significant influence of sociocultural aspects. According to Vygotsky's theory, it is the social interaction that plays an unquestionable role within education; it determines the psychogenesis of pupil's cognition. In relation to this, Vygotsky talks about the so called zone of proximal development. It may be understood as a period when a child approaches a new developmental stage without reaching it; however, under certain conditions (particularly with adult's guidance) he/she can reach it more easily compared to unaided spontaneous development. The zone of proximal development is characterised as a distance between the current level of performance (i.e. current level of a child's ability to problem-solving) and the potential developmental stage. The distance may be overcome with some guidance of a teacher, an adult or a more advanced child ${ }^{17}$. It is necessary to monitor the quality of social interaction in the education process (particularly a teacher's task), to see how the pupil with intellectual disability acquires the message content, whether he/she avoids the mere mechanical imitation and acquires fundamental components (e.g. of curriculum).

In a mainstream school where pupils with intellectual disability are integrated, the intact pupils are often monitored for their performance (results), specifically in academic and social areas. Authors Sharpe, York and Knight

${ }^{15}$ For example: J. Downing, Inclusive Education for High School Students with Severe Intellectual Disabilities: Supporting Communication, Augmentative and Alternative Communication, 2005, 21, 2; S. Copeland, J. Cosbey, Making Progress in the General Curriculum: Rethinking Effective Instructional Practices, Research \& Practice for Persons with Severe Disabilities, 2008-2009, 33-34, 4-1.; R. Slavin, Educational Psychology: Theory and Practice, Harlow 2011.

${ }^{16}$ L. Tipton, L. Christensen, J. Blacher, Friendship Quality in Adolescents with and without an Intellectual Disability, Journal of Applied Research in Intellectual Disabilities, 2013, 26, 6.

17 L.S. Vygotskij, Psychologie myšlení a řěci, Praha 2004, p. 72. 
state that the inclusion of pupils with disability is not associated with a reduction in academic performance of intact pupils as feared by many (inclusion opponents) ${ }^{18}$. Relevant research has also refuted concerns of teachers and parents of intact pupils who consider the cooperation of their children with pupils with disabilities as unhelpful and detrimental to their academic results ${ }^{19}$. Contrarily, studies propose that the presence of pupils with disabilities in a mainstream classroom has a beneficial effect on interpersonal, social and civil competencies of intact pupils ${ }^{20}$ which is in compliance with the requirements of inclusive education (in a wider sense with the value preference of developed democratic countries). Due to the current concept of education in the Czech Republic which follows and supports the inclusive trend, it is necessary to monitor the level of education of intact primary school pupils (in regard to their cognitive skills and identity) as well as how they form and develop their key social and personal competencies. The key competencies present a summary of knowledge, skills, attitudes and values that are important for personal development and success of every member of society ${ }^{21}$. In today's society the pupils without disabilities should be able to form a high quality interpersonal rapport and to provide support to those limited by disability (even more so to people with intellectual disability). However, this requires their preconceptions about intellectual disability to be void of severe misconceptions (both cognitive and affective components). Such misconceptions clearly limit the acquisition of vitally important competencies.

\section{Conclusion}

Inclusive education which has been favoured by the Czech education system in the last few years (but rather on a theoretical level) expresses legitimate requirements cultivated in line with the qualities of Czech postmodern democratic society. Transformations in areas of education that abandon segregation and separation of pupils with special educational needs into practical and special schools are related to many factors (political,

${ }^{18}$ M. Sharpe, J. York, J. Knight, Effects of Inclusion on the Academic Performance of Classmates without Disabilities, Remedial \& Special Education, 1994, 15, 5.

19 P. Hunt et al., Achievement by All Students within the Context of Cooperative Learning Groups, Research and Practice for Persons with Severe Disabilities, 1994, 19, 4.

${ }^{20}$ B. D'Alonzo, G. Giordano, D. Vanleeuwen, Perceptions by Teachers about the Benefits and Liabilities of Inclusion, Preventing School Failure, 1997, 42, 1.

${ }^{21}$ Framework Educational Programme for Elementary Education in Czech Republic (with changes to 1. 9. 2013), Praha 2007. 
economic, or social). To enable inclusive education to be functional in practice (not as the value concept) the barriers at macrosocial, mezzosocial and microsocial levels need to be defeated as they significantly influence and predict the success of the transformative endeavour. In a mainstream classroom environment (i.e. at microsocial level) the focus on psychosocial barriers is fully justified; these can inhibit inclusive efforts. Current demands in education put a great strain on pupils in area of cognition and performance. However, the emphasis needs to be given to the all-round development of pupils, particularly in areas of interpersonal rapport and personality. Reform efforts aiming at inclusive education must be inevitably reflected at various stages: for instance, in the changing approach of the concept of a human being towards the holistic concept, in attitude updates of intact pupils, or in educational activities directed at civil and communal coexistence in widely heterogeneous population. In line with the paradigm shift of the current education and in regard to current research trends (inclusive) in pedagogy and psychology, the aim to understand pupils' preconceptions (what knowledge and attitudes intact pupils have) about their peers with various disabilities has gained importance. School authorities (teachers) then need to overcome the psychosocial barriers of intact pupils appropriately. They tend to present as false notions (misconceptions) that are deeply ingrained consequently forming rigid and hostile attitudes and stereotypes. They often lead to discrimination towards vulnerable groups of people with disability. If the misconceptions are not modified for any reasons, they may prevail until adulthood. The relevant behavioural patterns and attitudes of the intact population towards people with disabilities could indicate to some extent the qualities of a democratic and tolerant society.

Acknowledgment. This study was possible thanks to a full support of the grant project GA UK No. 242213 "Preconceptions and Misconceptions to Selected Pathology Phenomena in Primary School Pupils". The author would like to give thanks to GA UK for its financial support, and to his workplace Charles University in Prague, Faculty of Education, Primary Education Dept. \& Institute for Professional Development, M. Rettigové 4, Prague 116 39, Czech Republic.

\section{BIBLIOGRAPHY}

Bartoňová M., Některé aspekty inkluzivního vzdělávání v podmínkách primárního školství, [In:] Inkluzioní vzdělávání v podmínkách současné české školy, Eds. M. Bartoňová, M. Vítková et al., Masarykova univerzita, Brno 2010. 
Copeland S., Cosbey J., Making Progress in the General Curriculum: Rethinking Effective Instructional Practices, Research \& Practice for Persons with Severe Disabilities, 20082009, 33-34, 4-1.

D’Alonzo B., Giordano G., Vanleeuwen D., Perceptions by Teachers about the Benefits and Liabilities of Inclusion, Preventing School Failure, 1997, 42, 1.

Downing J., Inclusive Education for High School Students with Severe Intellectual Disabilities: Supporting Communication, Augmentative and Alternative Communication, 2005, 21, 2.

Farrell P., Ainscow M. (Eds.), Making Special Education Inclusive: From Research to Practice, David Fulton, London 2002.

Fox C., Buchanan-Barrow E., Barrett M., Children's Understanding of Mental Illness: an Exploratory Study, Child: Care, Health and Development, 2007, 34, 1.

Framework Educational Programme for Elementary Education in Czech Republic (with changes to 1. 9. 2013), Výzkumný ústav pedagogický, Praha 2007.

Helmstetter E., Peck Ch., Giangreco M., Outcomes of Interactions with Peers with Moderate or Severe Disabilities: A Statewide Survey of High School Students, Journal of the Association for Persons with Severe Handicaps, 1994, 19, 4.

Hunt P., Staub D., Alwell M., Goetz L., Achievement by All Students within the Context of Cooperative Learning Groups, Research and Practice for Persons with Severe Disabilities, 1994, 19, 4.

International Standard Classification of Education, ISCED 2011. United Nations Educational, Scientific and Cultural Organization: Institute for Statistics 2011.

Laws G., Kelly E., The Attitudes and Friendship Intentions of Children in United Kingdom Mainstream Schools towards Peers with Physical or Intellectual Disabilities, International Journal of Disability, Development and Education, 2005, 52, 2.

Lebeer J., (Ed.), Programy pro rozvoj myšleni dětí s odchylkami vývoje: podpora začleňování znevýhodněných dětí do běžného vzděláváni, Portál, Praha 2006.

McDougall J., Dewit D., King G., Miller L., Killip S., High School-Aged Youths' Attitudes toward their Peers with Disabilities: The Role of School and Student Interpersonal Factors, International Journal of Disability, Development and Education. 2004, 51, 3.

Scior K., Public Awareness, Attitudes and Beliefs Regarding Intellectual Disability: A Systematic Review, Research in Developmental Disabilities, 2011, 32, 6.

Sharpe M., York J., Knight J., Effects of Inclusion on the Academic Performance of Classmates without Disabilities, Remedial \& Special Education, 1994, 15, 5.

Sherman J., Sherman S., Preventing Mobility Barriers to Inclusion for People with Intellectual Disabilities, Journal of Policy and Practice in Intellectual Disabilities, 2013, 10, 4.

Slavin R., Educational Psychology: Theory and Practice, Pearson, Harlow 2011.

Slowík J., Komunikace s lidmi s postižením, Portál, Praha 2010.

Statistická ročenka školství 2009/2010 až 2013/2014 - výkonové ukazatele, Ministerstvo školství, mládeže a tělovýchovy, Praha [cit. 2015-06-06], from: http://toiler.uiv.cz/ rocenka/rocenka.asp

Šafr J., Bayer I., Sedláčková M., Sociální koheze. Teorie, koncepty a analytická východiska, Sociologický časopis/ Czech sociological review, 2008, 44, 2.

Švarcová I., Mentální retardace: Vzdělávání, výchova, sociální péče, Portál, Praha 2006.

Tipton L., Christensen L., Blacher J., Friendship Quality in Adolescents with and without an Intellectual Disability, Journal of Applied Research in Intellectual Disabilities, 2013, 26, 6.

United Nations Educational, Scientific and Cultural Organization, Guidelines for Inclusion: Ensuring Access to Education for All, UNESCO, Paris 2005.

Vágnerová M., Hadj-Moussová Z., Štech S., Psychologie handicapu, Karolinum, Praha 2001. Vygotskij L.S., Psychologie myšlení a řeči, Portál, Praha 2004. 